\title{
Performing Political Persuasion in the United States in the Early Years of the Republic
}

\section{Tomáš KAČER}

\footnotetext{
Author:

Tomáš Kačer

Masaryk University, Czech Republic

kacer@phil.muni.cz

https://orcid.org/0000-0003-4809-7887

Date of reception: 15/02/2021

Date of acceptance: $26 / 06 / 2021$

Citation:

Kačer, Tomáš. 2021. "Performing Political Persuasion in the United States in the Early Years of the Republic." Alicante Journal of English Studies 35: 61-74

https://doi.org/10.14198/raei.2021.35.03

(C) 2021 Tomáš Kačer

Licence: This work is licensed under a Creative Commons Attribution 4.0 International License (CC BY 4.0)

\section{(C) (1)}

\begin{abstract}
:
Theater productions were born out of a paradox in the United States of the Revolutionary War and shortly afterwards. While the nation's dominant ideology was anti-theatrical, theater often served a nationalist agenda, co-defining the new American nation and its nascent identities - such were, for example, productions of Joseph Addison's Cato at Valley Forge in 1778 and William Dunlap's André at the New Park in New York in 1798. These theater events empowered the audience to publicly perform their national identity as Americans and exercise their republican fervor. Similarly, a production of Bunker-Hill by J. D. Burk at the Haymarket in Boston in 1797 was crucial in helping define the social and political identities of its audiences, who were motivated to attend the performances as an expression of their partisan preferences. This article shows that literary, theatrical and social practices served to constitute performatively the early American national identity.
\end{abstract}

Keywords: theater history; performance studies; American theater; history of the United States $-18^{\text {th }}$ century. 
Although various seminal concepts of performativity, such as Austin 1962, date back nearly sixty years, recent years have seen a renewed interest in performance and performance studies among scholars from a variety of fields. These contributions further develop the original ideas of thinkers such as the literary critic Kenneth Burke, linguist John L. Austin and sociologist Erving Goffman that marked the beginning of what has been regarded as "the performative turn" (Schechner 2015, 158-159). Performance Studies has since been established as a discipline, thanks to the creative energy of the likes of Richard Schechner and his visionary collaborators - such as the anthropologist Victor Turner, who "placed performance at the center of a larger view of culture as constructed, embodied, and processual" (Hamera 2006, 46). Turner's studies of rituals have facilitated a better understanding of various cultural practices and phenomena. Judith Butler introduced a political view of the performance as a constitutive force of fluid, performative categories such as "gender" and "race". Since then, the power of the performative to assert a much wider assortment of categories, such as nationality and partisanship, has been accepted by a number of performance scholars.

A more or less concise theory of the multifaceted field has been formulated, for instance in the comprehensive overviews Performance Studies: An Introduction by Schechner (2016 [2002]) and Performance: A Critical Introduction by Marvin Carlson (2018 [1996]). In line with these developments, this article does not understand categories such as nationality and class as objective, but rather as fundamentally performative. The paper explores how notions of performativity help understand historical events as dynamic, constitutive activities, which have helped to define some of the most fundamental issues in American culture. In the following pages, issues such as republicanism, American national identity, and a (dis-)belief in a social class system will be shown as constituted in performance through an active participation of performers as well as audiences. Three case studies will show, (1) how a text performs republican values (in the case of a historic performance of Joseph Addison's Cato for officers of the Continental army at Valley Forge on May 11, 1778); (2) how a theater production constitutes national identity through symbolic gestures (as in the performance of André at the New Park Theatre in New York on March 30, 1798); and (3) how theater attendance as such becomes a performance of political views, as in a visit to the Haymarket theater in Boston to see Bunker-Hill by J. D. Burk in February 1797. The article will thus present a performative approach to literary, theatrical and sociological practices from the early history of the United States.

The United States of the late $18^{\text {th }}$ century was not a theater-friendly country. Besides the general hardships of colonial and early republican life, which left little 
space for leisure and a relative paucity of theater institutions such as buildings and companies, theater was considered morally corrupt and inappropriate in most states, especially New England. This "tradition of distrust in many kinds of artistic representation" (Gainor 1999, 8) was a result of a Puritan heritage, which dominated the discourse on pastime activities in most American states. Even in Williamsburg, Virginia, and Philadelphia, which were the theatrical hubs of the time, theaters and public performances were tolerated at best. This is well illustrated in the fact that the first Continental Congress meeting in Philadelphia passed a ban on theater as one of its first official acts in 1774: "its members committed themselves to discountenancing and discouraging 'every species of extravagance and dissipation, especially all horse-racing, and all kinds of gaming, cock-fighting, exhibition of shews, plays, and other expensive diversions and entertainments'" (Wilmeth and Bigsby 1998, 5). In other words, one of the first legal actions by the American legislature was, effectively, a ban of the theater.

By way of coping with this handicap, theaters incorporated various other functions besides mere entertainment into productions. Theater shows were often advertised as moral dialogues, since various classical tragedies revolve around moral questions. More importantly, though, theaters became an important part of the ongoing political struggle that was underway. Theater productions of plays opposing tyranny, such as Richard III, and promoting Roman republican values, such as Julius Caesar - to provide illustrative examples from Shakespeare's oeuvre - became manifestations of the period's American revolutionary spirit. Following upon Austin, a performative is a unique occurrence of an utterance in a particular spatial and temporal context. In the theater, dramatic speeches gain a context-dependent meaning depending on the context of a performance. This explains why the above Shakespearean examples resonated with the American revolutionaries despite the fact that they had been written for different audiences and with different intentions. Political plays then attracted audiences who did not primarily enter the theater for entertainment or aesthetic pleasure, but rather as a political arena: "The spirit of revolution in the United States created theater as a sphere for political discourse, but one much more robust and raucous than the rational deliberation envisioned by Jürgen Habermas. The audience was both a crowd and a public, or a hybrid of the two" (Butsch 2008, 24-25). It may seem like a paradox, thus, that the institution of theater was deemed immoral and banned on the one hand by the early republicans, while it served as an arena for a political discussion promoting republican ideas. To go to see a play was an actual performance of democratic, patriotic, and partisan values.

Revolutionary America abounded with performances that reached far beyond the sphere of the theater. As Jacques Derrida (1986) showed, the founding act of the United States of America, the signing of the Declaration of Independence, 
was itself a performance where the performer - the people's representative is being created in the act. The document is a declarative statement but the question remains, "who signs, and with what so-called proper name, the declarative act which founds an institution?" (emphasis in the original; Derrida 1986, 8). And since there was no American people before this act, there could be no signer of the Declaration, either. The only possible reading is thus a performative one: by the act of signing, the signer is established together with the people he represents by his signature in "a vibrant act of faith" (Derrida 1986, 12). The Declaration is a performative of the American nation, its representatives and the existence of a country, together with its name, the united states of America all at once. It takes its authority not from the law or custom - as so many performatives studied by Austin - but from God himself.

The signing of the Declaration of Independence, as analyzed by Derrida, serves as a case in point that the United States of the late $18^{\text {th }}$ century built its identity in a political process of self-fashioning. The national identity, values, and politics were performed on frequent public occasions, a lot of which were related to the theater as the political forum: "Theaters were actively used for these political performances and they flourished as never before. Formerly condemned as an aristocratic pastime, theater gained newfound legitimacy as one of few indoor gathering spaces for republican political participation" (Butsch 2008, 25). Theaters became the space for political action establishing, defining, and shaping the new American identity: "The stage, then, becomes [...] a platform where players and audience may enact conceptions of identity and community, where 'America' becomes both the subject and the consequence of artistic, cultural, and social negotiation" (Mason 1999, 4). In other words, theaters supplied the context where politics was performed and were a part of politics.

The following part of this article deals with the case studies, exemplifying performances of various early American political activities in nationalist speech acts, gestures, and social activities. Theater performance of Cato by Joseph Addison by the American army during the Revolutionary war will illustrate that a mere staging of a play is a performative act. In particular, this theatrical event became a political action of reaffirming a republican identity among American rebels by recontextualizing the British play into the American revolutionary settings. In other words, to stage the play was a performative act in itself.

Joseph Addison's Cato (1712) is an Augustan tragedy about the eponymous Roman senator's futile struggle with Julius Caesar. Yet, "scarcely anyone reads Addison's tragedy anymore, for reasons that are apparent from its clumsy structure and belabored political intrigues" (Fuller 1999, 131), as well as the heavy "ironclad verse" (Fuller 1999, 128). The play was nevertheless a longstanding favorite of audiences on both shores of the Atlantic at the time, with 
"an ardent admirer" (Bryan 2010, 123) within the ranks of the rebellious Americans: General George Washington himself.

Washington assembled his officers at the encampment at Valley Forge, where the Continental Army had spent a long and debilitating winter, on May 11, 1778 , to watch a hastily rehearsed performance of the play. This was no frivolous matter, but a serious war-time maneuver: it aimed to boost the troops' morale as well as send out a clear message about Americans' determination: "by the time of the Valley Forge Cato, theatrical productions had become acts of war - bombastic salvos in a campaign whose arsenal included not only rifles and cannons but culture as well" (Fuller 1999, 130). A republican ethos of the play resonated strongly among soldiers who regarded it as a confirmation of the righteous nature of their rebellion against tyrannical monarchy.

When the Numidian prince Juba asks Cato for his daughter Marcia's hand in the midst of the politically tumultuous time, Cato ponders the nature of virtue, both in romantic and stately matters: "It is not now time to talk of aught/ But chains or conquest, liberty or death" (Addison 1713, Act 2, Scene 1). He acknowledges that virtue is only born from action, not from a philosophical discussion. His conclusion is to put the stately matters to the fore since it is in the fight for freedom that virtue is born. There is no reason to live - and thus no prospect of marriage either - without an active participation in a fight against tyranny. His "declamation of freedom" (Saxon 2011, 98) resonated with the assembled officers, as it used a well-known phrasing of a central theme of the American revolutionary war. Continental army officers identified themselves during the performance as inheritors of ancient Roman patriots rebelling against Caesar's rising tyrannical power.

The performance at Valley Forge helped to define the officers present as audience. It established Cato as the model of republicanism. The officers saw his beliefs, behavior, and sacrifices as parallel to their own and, vice versa, the performers spoke directly to the audience when addressing Cato, as when Juba praises Cato's political stance and personal qualities in the opening scene of the play:

Juba: A Roman soul is bent on higher views;

Turn up thy eyes to Cato;

There may'st thou see to what a godlike height

The Roman virtues lift up mortal man.

While good, and just, and anxious for his friends,

He's still severely bent against himself;

And when his fortune sets before him all

The pomps and pleasures that his soul can wish,

His rigid virtue will accept of none. (Addison 1713, Act 1, Scene 1)

Alicante Journal of English Studies, Issue 35, 2021, pages 61-74 
The verses are an explicit expression of an idealized republican at war with tyrannical rule. As such, they are performative, establishing a norm for an ideal of American's political values as well as personal traits. Moreover, they establish a new nobility - instead of the British corrupt, hereditary one, the new American nobility is solely based on virtues. The "Roman virtues" (Addison 1713, Act 1, Scene 1) of republicanism become American ones. Thus, the performance establishes a direct link with republican ideology, presents an idealized form of the American righteous rebellion, and substitutes for the corrupt British nobility a concept of a virtuous one, which is republican.

As Fuller (1999) states, "the audience response to the Valley Forge Cato is impossible to reconstruct" (136). Yet, it is possible to illustrate its effect by commenting on the impact of the performance, which has become one of the defining moments in the creation of the revolutionary American identity. There is only scarce evidence of the event itself, encapsulated in a single piece of historical evidence: a letter from a stationed soldier and a member of the audience, William Bradford, Jr., to his younger sister written three days after the performance. Bradford's letter has been quoted as a proof that the performance boosted the morale of the army, "a gift from Washington and his elite commanders to the weary men who had survived the full encampment and to the many new recruits who had reconstituted the Continental army" (Bryan 2010, 123). Yet, as Bryan (2010) concludes from his research of available evidence, there is no proof that the production was a great open-air spectacle accommodating a large audience. Quite the contrary, the evidence suggests that the audience was very limited. Still, supporters of the American revolution capitalized on the republican imagery of the play and have created a false mythology around the Valley Forge performance as a morale booster for the weary army.

This strategy worked and the myth was established. Before the turn of the century, "four or five" American editions of Cato were printed and sold in large quantities as republican artifacts (Fuller 1999, 136). These copies include an epilogue "explicitly linking Washington and the hero of Addison's play". Jonathan Mitchell Sewall's direct parallel between the play and the American revolutionary institutions and representatives is explicit: "Our senate, too, the same bold deed has done, / And for a Cato, arm'd a WASHINGTON!" (Bryan 2010, 125). The performance of the tragedy Cato at Valley Forge entered the American national imagery as a performance of a revolt against tyrannical rule and a celebration of republican virtues, which, through the performance itself, was defined and established. The fact that the play was an English hit of the time remains a matter of historical irony.

The years following the American Revolutionary War saw a rapid development of theater in the United States. The center of this artistic activity moved to New 
York, where it would eventually remain. William Dunlap was one of the most important figures propelling this development as a historian of the American visual and performing arts, theater manager, translator, and playwright. As someone who obtained his education and spent a substantial portion of his life, including the recent wartime years, in Great Britain, he sided politically rather with the loyalists to the crown, yet he saw it as his duty to advance American theater and dedicated all his talent as well as possessions to this goal. In 1798, he realized that the new country lacked a native tragedy in verse, which he also saw as a commercially promising endeavor: "Perhaps Dunlap hoped to cash in on the popularity of recent history as a stage subject by himself turning to a war he missed, the American Revolution" (Richards 1997, 59). The result was the first tragedy in verse written in the United States of America, André.

The play "is based on the 1780 capture, trial, and execution of British officer Major John André, who conspired with the Continental general Benedict Arnold to surrender West Point to the British" (Dunlap and Miller 2005, xiv). Dunlap expected he could count on the audience's fresh memories of the war as well as the protagonist, who had been a popular socialite in wartime New York and a person actively participating in the British military theater activities. The story of André's capture and execution resonated strongly among New Yorkers. The play begins with André's capture, and proceeds to his death sentence and, finally, execution. It involves no dramatic twists and its plot can be summarized a series of supplications of André's friends, admirers, and relatives to the General, but all of them fail. The General - who clearly represents Washington - is torn between two loyalties: one toward a military duty, and the other toward an officer's virtue. While the former forces him to convict and execute the British spy Captain André, the latter pressures him to pardon André, since he has always acted fairly and proved his virtuousness. However, the General is not moved by all the supplications or his own sympathy, and sentences André to death.

Captain Bland, the General's aide, reminds the General of Andrés' virtuous behavior in the past when he saved Bland's life, and the two thus had become friends for life. But the General dismisses the plea. At that point, Bland understands that his appeal for André's life has failed. He realizes that the United States army prefers victory to virtue, which is in conflict with his code of honor. Despite the General's approval of his attempt to save his friend, Bland parts symbolically with the cause of the Revolution:

General: [...] Thy merits are not overlook'd.

Promotion shall immediately attend thee.

Bland: Pardon me, Sir, I never shall deserve it.

The country that forgets to reverence virtue [...]

Alicante Journal of English Studies, Issue 35, 2021, pages 61-74 


\section{I serve not. [...] Thus from my helm}

I tear, what once I proudly thought, the badge

Of virtuous fellowship.

(Tears the cockade from his helmet.)

My sword I keep. (Dunlap 1997 [1798], 86-87)

In Bland's view, there is no honor in wearing the symbol of the American Revolution, the cockade. He throws it to the floor in an act of a symbolic denunciation.

This irreverent act was performed in front of New York audiences, who may have been as torn apart about André as the General in the play, but just like the General, they were clear about their loyalty: "The audience thought this act unpatriotic and hissed the actor" (Dunlap and Miller 2005, xiv). But clearly, their new republican loyalty to the United States prevailed. Ironically, this gesture prompted a response in the audience members, who in return expressed their loyalty to their new country; in other words, the audience performed their citizenship.

After the first performance on March 30, 1798, "the feeling excited by the incident was propagated out of doors" of the New Park Theatre (Dunlap and Miller 2005, 226). Dunlap realized that he needed to change the script so that the anti-American gesture was revoked before the play was over in the following performances: "As a sequel to the affair of the cockade, the Author has added the following lines, which the reader is requested to insert [...] instead of the lines he will find there, which were printed before the piece was represented" (Dunlap 1997 [1798], 65).

Further in the Preface, he has supplied new lines:

Bland: [...] Even in the presence of the first of men

Did I abjure the service of my country,

And reft my helmet of that glorious badge

Which graces even the brow of Washington. [...]

M'Donald. [...] To me, in trust, he gave this badge disclaim'd,

With power, when thou should'st see thy wrongful error,

From him, to reinstate it in thy helm,

And thee in his high favour.

(Gives the cockade.)

Bland (Takes the cockade and replaces it.) [...] Ne'er shall my helmet

Lack again its proudest, noblest ornament,

Until my country knows the rest of peace,

Or Bland the peace of death! (Dunlap 1997 [1798], 65-66) 
Bland, who in Scene 3, Act 1 tore off the cockade, now in Act 5, Scene 1, accepts the General's view after his friend and fellow officer M'Donald's appeals to Bland's sense of military duty. Bland can see now that the General has acted against his personal will, a necessary sacrifice at war, which is fought for the right cause.

Historical sources such as Dunlap (2005) do not mention how the audience received this altered treatment of the desecrated national symbol. A few scenes from André were then incorporated into The Glory of Columbia - Her Yeomanry! in 1803, "a more overtly patriotic vehicle [...] which became a July fourth staple for years afterward" (Richards 1997, 61). This play was a more traditional expression of nationalism, with displays of the national flag, nationalist dialogues, and patriotic songs. Thus, a play that performed an act of anti-American criticism in 1798 became a nationalist spectacle, a performance of full-blown nationalist propaganda only five years later. Perhaps, Dunlap could see that in the postwar period, a blunt performance of national identity would be received by the audience with more ease than a complicatedly structured performance of a criticism of breaking with the nation's core values in a symbolic act - a theatrical gesture.

That being said, it is necessary to note that there has been no single American national identity. As Jeffrey A. Richards (2005) writes in his study of constructions of American identities in the early United States, "there is no monolithic 'American' identity to which all residents of the United States subscribe - only a changeable cluster of identities that individuals or groups might recognize as pertaining to them" (19). Performances like that of André were an opportunity for American citizens to assemble and practice democracy by establishing an imagined community (Anderson 1991) of Americans for the duration of the performance. The audience became a community of strangers, who may have had their differences over several details of the issue, yet shared core values and identified themselves with the same markers of their identity in the making, such as that of the cockade.

Post-revolutionary Boston's theater culture provides yet another example of the performative power of the period's theater over establishing republican identities. The capital of Massachusetts was at the heart of the Puritan antitheatrical prejudice. Several prominent Massachusetts politicians, such as the Governor John Hancock, effectively prevented arrival of professional theater to the city until the end of his tenure in 1793 when, at last, "the Legislature of Massachusetts repealed the law against theatrical amusements" (Dunlap and Miller 2005, 133). In February of the following year, Boston Theatre - later known as The Federal Street Theatre - opened and it "was soon considered the finest theater in the country" (Boston Anatheum Theatre History). The choice of the first production reflected the post-revolutionary sentiment. Gustavus Vasa, written in 1739 by Henry Brook, is a tragedy about an eponymous Swedish 
rebellion leader. Boston audiences saw a direct parallel between Vasa's fight for freedom and their own recent history. Moreover, "the performance of a play wellknown to have been censored in Britain was an act in itself" (Strand 1999, 26). The managers and audience saw it as an important symbolic break with the British.

In the following years, however, the development of theatrical culture in Boston reflected a political struggle among the two American political parties, the Federalists and the Democratic Republicans. It was common in the early republic's politics that "political factions in America used the theater to promote contradictory political agendas" (Wilmer 1999, 1). This was mostly done by the choice of plays and commissioning of prologues celebrating a particular party by theater managers who - like the above-mentioned William Dunlap - had their own political agendas. A partisan struggle, however, became more extreme in Boston in the mid-1790s: "The theatres in Boston and New York [...] were particularly affected by political divisions, and in Boston so much so that, in the 1769-97 season, its two theatres attracted separate partisan audiences" (Wilmer 1999, 3). Three years after the Federal Street Theatre, a new theater opened in Boston, the Haymarket.

The Federal Street Theatre's shareholders capitalized on the success of Gustavus Vasa in 1794 and continued to propagate the post-revolutionary ethos of Washington's republic. The theater's management became strongly pro-Federalist and the party's ideology became visible in the theater's policies. Naturally, it "encouraged pro-Federalist pieces" on the bill (Wilmer 1999, 5). It introduced stark differences in ticket prices to distinguish the high society from common citizens in the pit and gallery. Architecturally, the theater "emphasized implied social distinctions in the organization of traffic to and from the playhouse: a covered arcade for coaches on Federal Street supplied entrance to the boxes through a large lobby; the pit and gallery each had separate entrances without lobbies" (Strand 1999, 22). The management further insisted that the stockholders should only include "the most respectable citizens" (Strand 1999, 23). The most striking element of this competition between the two Boston theaters was that the audiences were forced to take a side. Once they attended one of the two theaters, they were strongly discouraged from attending the other: "If [Federalist managers] were unable to sell all the tickets, the shareholders would apparently give the remaining tickets away on condition that the recipients would refuse to patronize the rival Haymarket Theatre" (Wilmer 1999, 4). Theater attendance became a performance of party affiliation.

On the contrary, the Haymarket Theatre "fostered a Democratic Republican agenda" (Wilmer 1999, 5). From the moment when it was founded, it "was designed as a more radically democratic institution" than the Federal Street 
Theatre (Strand 1999, 24). It collected funding from all social strata, was overtly egalitarian, refused a paywall, had a rather plain, unsophisticated auditorium, and was generally more inclusive.

The Democratic Republican agenda of the Haymarket was reflected in the choice of plays. Some of them "were seen as straightforward bids to please Republican stockholders" (Strand 1999, 25). One of the most overt examples of this Democratic Republican billing is the 1797 production of John Daly Burk's Bunker-Hill; or, The Death of General Warren. Burk was an open supporter of the party and his "adherence to Democratic Republican principles was clearly expressed in Bunker-Hill, which he dedicated to Aaron Burr (a leading Democratic Republican [...])" (Wilmer 1999, 6). The play depicts a melodramatic story of the popular national hero and a Massachusetts native, General Warren, his fight against the British, the battle of Bunker-Hill, and his heroic death. The production was extremely popular at the Haymarket, as it accorded with the postwar patriotic sentiment.

Burk "depicted General Warren [...] as an altruistic patriot who does not demand a privileged social position but wants to do whatever he can to help his countrymen" (Wilmer 1999, 6). Despite his military rank, he considers himself equal to all other soldiers. Republican citizenship, which is egalitarian in principle, is the highest virtue for General Warren:

General Warren: And shall I then, inglorious, stay behind, While my brave countrymen are braving death? [...]

No - Liberty will ne'er be woo'd by halves,

But like the jealous female, must have all

The lover's heart or none. (Burk 1831 [1797], 39)

The soliloquy appeals to notions of bravery and liberty, associating them with qualities of the heart rather than rank. Moreover, General Warren is inspired by his countrymen; it is the common American citizen who sets an example of true patriotic behavior and military service.

As General Warren is dying in the final battle, he becomes an idealized representation of a republican citizen. He praises only virtue, which must be earned and is equally achievable by anyone and sees hereditary titles as degenerate. He explicitly scorns aristocracy:

General Warren: All riches and rewards my soul detests,

Which are not earn'd by virtue: I prefer

One hour of life, spent in my country's services,

To ages wasted midst a servile herd 
Of lazy, abject, fawning, cringing courtiers. (emphasis in the original; Burk 1831 [1797], 63)

He refuses all personal profit besides a symbolic gain. He dies in the close company of fellow soldiers, having substituted his personal ambitions to a sole item of value: a free American republic consisting of equal citizens. In the character of General Warren, Burk invests the American cause with the ethos of an idealistic struggle.

With its emphasis on egalitarianism and anti-aristocratic rhetoric, "Bunker-Hill was not simply a patriotic or nationalistic play. It affirmed Democratic Republican principles and attacked values held by the Federalists" (Wilmer 1999, 10-11). The play's rhetoric thus met the political goals of the Haymarket Theatre's management. In effect, Haymarket performances of Bunker-Hill became assemblies of the Boston Democratic Republicans. The audience performed their political persuasion by theater attendance, which established their partisan identities.

Burk's play propagated the Democratic Republican agenda against the Federalist one, but it still remained an American patriotic spectacle. "By setting it during the War of Independence, Burk integrated his partisan politics into a nationalistic frame in order to appeal to a wide audience" (Wilmer 1999, 8). The play was also performed in New York, where the partisan division among theaters was not as explicit as in Boston at that time, possibly due to the fact that there were several competing theaters in New York, while there were exactly two in Boston. The two parties thus saw the Boston theatrical scene as an arena for partisan struggle, in a sense a forum, which served to express political views, contest them, and perform political loyalties. This was a great shift for Bostonians' political elites since the adoption of an antitheatrical ordinance in 1750 .

In conclusion, this article has discussed various performative aspects of several theater productions in the early history of the United States. It shows that theater attendance is in itself the performance of a political affiliation, particularly so at a tumultuous time such as that of the War of Independence and the early post-war period. It has discussed the Valley Forge Cato performance for military officers as an act of duty, service, and honor; the audience's hostile response to the desecration of a national symbol - stomping on the cockade - at the New Park Theatre's production of André as an act of citizenship and American national identity; and attendance at Haymarket's Bunker-Hill as an act of affiliation to the Democratic Republican party. It has shown that an approach based on performance studies widens our perspective of understanding theater performance as a social practice, one where the rhetoric of the play is interpreted in relation to the actual time and place of the performance and in a creative exchange with audiences and their wider social context. 
Americans would go on throughout the nineteenth century and beyond to define and redefine themselves through their experiences as theater audiences. Their political and ideological identities will be shaped at productions of various abolitionist plays like the phenomenal Uncle Tom's Cabin, ${ }^{1}$ which would become an institution of its own kind. Their political allegiances will be redefined at war play, dealing with reminiscences of the Revolutionary War such as Joseph Jefferson's adaptation of Rip Van Winkle (1859) as well as propagating an ideological understanding of the Civil War in melodramatic renditions such as Bronson Howard's Shenandoah (1889). Throughout the nineteenth century, performances such as theater and related forms of entertainment will establish specifically American genres and forms, thus further shaping who Americans are as a nation, politically as well as culturally in the wider sense.

\section{Works cited}

Addison, Joseph. 1713. Cato. London. https://www.proquest.com/books/cato-1713/ [Accessed online on February 13, 2021]

AIKEN, George L. 1858. Uncle Tom's Cabin; or, Life Among the Lowly. A Domestic Drama in Six Acts. New York: Samuel French.

Anderson, Benedict. 1991. Imagined Communities. Reflections on the Origins and Spread of Nationalism. Revised edition. New York: Verso.

Austin, John Langshaw. 1962. How to Do Things with Words. $1^{\text {st }}$ edition. Oxford: Oxford University Press.

"Boston Anatheum Theater History". n.d. Boston Anatheum. https://www. bostonathenaeum.org/library/electronic-resources/boston-athenaeum-theatercollection/history [Accessed online on February 13, 2021]

Bryan, Mark Evans. 2010. "'Slideing into Monarchical extravagance': Cato at Valley Forge and the Testimony of William Bradford Jr." William \& Mary Quarterly 67 (1): 123-144. https://doi.org/10.5309/willmaryquar.67.1.123

BuRK, John Daly. 1831 [1797]. Bunker-Hill; or, The Death of General Warren. New York:

The Dunlap Society. https://archive.org/details/bunkerhillordea00burkgoog/ [Accessed online on February 13, 2021]

Butsch, Richard. 2008. The Citizen Audience: Crowds, Publics, and Individuals. New York: Routledge. https://doi.org/10.4324/9780203929032

1 There are dozens of adaptations of Harriet Beecher Stowe's novel for the theater. The most popular and frequently played theater adaptation is by George L. Aiken. Its first version was performed in 1852 and the script was finalized and published in 1858 under the title Uncle Tom's Cabin; or, Life Among the Lowly. A Domestic Drama in Six Acts (Aiken 1858). 
Carlson, Marvin. 2018 [1996]. Performance: A Critical Introduction. 3rd ed. London and New York: Routledge.

DerridA, Jacques. 1986. "Declarations of independence." Online. New Political Science 7 (1): 7-15. https://doi.org/10.1080/07393148608429608

Dunlap, William. 1997 [1798]. André. In Richards 1997, 58-108.

DunlaP, William, and Tice L. Miller. 2005. A History of the American Theatre from Its Origins to 1832. Urbana: University of Illinois Press.

Fuller, Randall. 1999. "Theaters of the American Revolution: The Valley Forge Cato and the Meschianza in Their Transcultural Contexts." Online. Early American Literature 34 (2): 126-146. https://doi.org/10.1353/wal.1999.0063

GaINOR, J. Ellen. 1999. "Introduction.” In Mason and Gainor 1999, 7-15.

Hamera, Judith. 2006. "Performance, Performativity, and Cultural Poiesis in Practices of Everyday Life." In The SAGE Handbook of Performance Studies, edited by D. Soyini Madison and Judith Hamera, 46-64. London: SAGE. https://doi. org/10.4135/9781412976145.n4

Mason, Jeffrey D. 1999. "American Stages (Curtain Raiser)." In Mason and Gainor 1999, 1-6.

Mason, Jeffrey D. and J. Ellen Gainor, editors. 1999. Performing America: Cultural Nationalism in American Theater. Ann Arbor: University of Michigan Press. https://doi.org/10.3998/mpub.16346

Richards, Jeffrey H. 1997. Early American drama. New York: Penguin Books.

- 2005. Drama, Theatre E Identity in the American New Republic. Cambridge: Cambridge University Press. https://doi.org/10.1017/CBO9780511486128

SAxOn, Theresa. 2011. American Theatre: History, Context, Form. Edinburgh: Edinburgh University Press.

SCHECHNER, Richard. 2015. Performed Imaginaries. New York: Routledge. https://doi. org/10.4324/9781315747514

- 2016 [2002]. Performance Studies: an Introduction. 3rd edition. New York: Routledge.

Strand, Ginger. 1999. "The Theater and the Republic: Defining Party on Early Boston's Rival Stages." In Mason and Gainor 1999, 19-36.

Wilmer, Stephen Elliot. 1999. "Partisan Theatre in the Early Years of the United States." Online. Theatre Survey 40 (2): 1-26. https://doi.org/10.1017/ S0040557400003537

Wilmeth, Don B. and Christopher Bigsby. 1998. The Cambridge History of American Theatre: Volume One: Beginnings to 1870. Cambridge: Cambridge University Press. https://doi.org/10.1017/CHOL9780521472043 